\title{
Tamlana agarivorans sp. nov., isolated from seawater off Jeju Island in Korea
}

\author{
Jung-Hoon Yoon, So-Jung Kang, Mi-Hwa Lee and Tae-Kwang Oh
}

Correspondence

Jung-Hoon Yoon

jhyoon@kribb.re.kr
Korea Research Institute of Bioscience and Biotechnology (KRIBB), PO Box 115, Yusong, Taejon, Republic of Korea

\begin{abstract}
A Gram-negative, non-motile, rod-shaped, agarolytic bacterial strain, designated JW-26 ${ }^{\top}$, was isolated from seawater off Jeju Island in Korea, and was subjected to a polyphasic taxonomic investigation. Strain $\mathrm{JW}-26^{\top}$ grew optimally at $\mathrm{pH} 7.0-8.0$, at $30{ }^{\circ} \mathrm{C}$ and in the presence of approximately $2 \%(\mathrm{w} / \mathrm{v}) \mathrm{NaCl}$. Phylogenetic analyses based on $16 \mathrm{~S}$ rRNA gene sequences revealed that strain JW-26 ${ }^{\top}$ joins Tamlana crocina $\mathrm{HST} 1-43^{\top}$, with which it exhibited a $16 \mathrm{~S}$ rRNA gene sequence similarity value of $95.5 \%$. Strain JW-26 ${ }^{\top}$ contained MK-6 as the predominant menaquinone and iso- $\mathrm{C}_{15: 0}, \mathrm{C}_{15: 0}$ and iso- $\mathrm{C}_{15: 1}$ as the major fatty acids. The DNA G+C content was $36.8 \mathrm{~mol} \%$. There were no distinct phenotypic and, particularly, chemotaxonomic properties to differentiate strain $\mathrm{JW}-26^{\top}$ from the genus Tamlana. DNA-DNA relatedness data and differential phenotypic properties, together with the phylogenetic distinctiveness, demonstrated that strain $\mathrm{JW}-26^{\top}$ is distinguishable from the type strain of $T$. crocina. On the basis of phenotypic, phylogenetic and genetic data, therefore, strain $\mathrm{JW}-26^{\top}$ represents a novel species within the genus Tamlana, for which the name Tamlana agarivorans sp. nov. is proposed. The type strain is $\mathrm{JW}-26^{\top}\left(=\mathrm{KCTC} 22176^{\top}=\right.$ CCUG $\left.55327^{\top}\right)$.
\end{abstract}

In the course of the screening of micro-organisms from seawater off Jeju Island in Korea, many bacterial strains belonging to the phylum Bacteroidetes have been isolated. One of these isolates, strain $\mathrm{JW}-26^{\mathrm{T}}$, which shows agardegrading activity, is the subject of this study. A comparative 16S rRNA gene sequence analysis showed that strain JW $-26^{\mathrm{T}}$ is phylogenetically related to the genera Tamlana and Algibacter. The aim of the present work was to determine the exact taxonomic position of strain JW$26^{\mathrm{T}}$ by using a polyphasic characterization that included determination of the phenotypic properties and a detailed phylogenetic investigation based on $16 \mathrm{~S}$ rRNA gene sequences.

Strain $\mathrm{JW}-26^{\mathrm{T}}$ was isolated by means of the standard dilution plating technique at $30{ }^{\circ} \mathrm{C}$ on marine agar 2216 (MA; Difco). Tamlana crocina KCTC $12721^{\mathrm{T}}$ was used as a reference strain for phenotypic characterization and DNADNA hybridization. The morphological, physiological and biochemical characteristics of strain JW-26 ${ }^{\mathrm{T}}$ were investigated using routine cultivation on MA at $30{ }^{\circ} \mathrm{C}$. The cell morphology was examined by using light microscopy (E600; Nikon) and transmission electron microscopy (CM20; Philips). Flagellation was determined by using transmission electron microscopy on cells from an exponentially growing culture negatively stained with $1 \%(\mathrm{w} / \mathrm{v})$ phosphotungstic acid. Grids were examined after being

The GenBank/EMBL/DDBJ accession number for the 16S rRNA gene sequence of strain $\mathrm{JW}-26^{\top}$ is EU221275. air-dried. The Gram reaction was determined by using the bioMérieux Gram stain kit according to the manufacturer's instructions. Gliding motility was investigated as described by Bowman (2000). Growth under anaerobic conditions was determined after incubation in a Forma anaerobic chamber on MA and on MA supplemented with potassium nitrate $(0.1 \%, \mathrm{w} / \mathrm{v})$, both of which had been prepared anaerobically under a nitrogen atmosphere. Growth in the absence of $\mathrm{NaCl}$ was investigated using trypticase soy broth prepared according to the formula of the Difco medium except that $\mathrm{NaCl}$ was excluded. Growth at various $\mathrm{NaCl}$ concentrations $(0.5 \%, \mathrm{w} / \mathrm{v}$, and 1.0 $10.0 \%, \mathrm{w} / \mathrm{v}$, in increments of $1.0 \%$ ) was investigated in marine broth 2216 (MB; Difco) and trypticase soy broth (Difco). Growth at various temperatures $(4,10,15,20,22$, 25 and $28{ }^{\circ} \mathrm{C}$ and $30-40{ }^{\circ} \mathrm{C}$ in $1{ }^{\circ} \mathrm{C}$ increments) was measured on $\mathrm{MA}$. The $\mathrm{pH}$ range for growth was determined in $\mathrm{MB}$ adjusted to various $\mathrm{pH}$ values ( $\mathrm{pH} 4.5-9.5$, in increments of $0.5 \mathrm{pH}$ units) by the addition of $\mathrm{HCl}$ or $\mathrm{Na}_{2} \mathrm{CO}_{3}$. Catalase and oxidase activities were determined as described by Cowan \& Steel (1965). Hydrolysis of casein, starch, Tweens 20, 40, 60 and 80, hypoxanthine, tyrosine and xanthine was tested on MA, using the substrate concentrations described by Cowan \& Steel (1965). Hydrolysis of aesculin, gelatin and urea and reduction of nitrate were investigated as described previously (Lányí, 1987) with the modification that artificial seawater was used for the preparation of media. The artificial seawater contained $\left(\mathrm{l}^{-1}\right.$ distilled water) $23.6 \mathrm{~g}$ 
$\mathrm{NaCl}, \quad 0.64 \mathrm{~g} \quad \mathrm{KCl}, \quad 4.53 \mathrm{~g} \quad \mathrm{MgCl}_{2} \cdot 6 \mathrm{H}_{2} \mathrm{O}, \quad 5.94 \mathrm{~g}$ $\mathrm{MgSO}_{4} \cdot 7 \mathrm{H}_{2} \mathrm{O}$ and $1.3 \mathrm{~g} \mathrm{CaCl} \cdot 2 \mathrm{H}_{2} \mathrm{O}$ (Bruns et al., 2001). $\mathrm{H}_{2} \mathrm{~S}$ production was tested as described previously (Bruns et al., 2001). The presence of flexirubin-type pigments was investigated as described by Reichenbach (1992). For pigment-absorption spectrum analysis, strain $\mathrm{JW}-26^{\mathrm{T}}$ was cultivated aerobically in the dark at $30{ }^{\circ} \mathrm{C}$ in $\mathrm{MB}$. The culture was centrifuged, washed twice using a MOPS buffer (MOPS/NaOH, $0.01 \mathrm{M}$; KCl, $0.1 \mathrm{M} ; \mathrm{MgCl}_{2}$, $0.001 \mathrm{M} ; \mathrm{pH} 7.5$ ) and disrupted by sonication with a Branson 450 sonifier. After removal of cell debris by centrifugation, the supernatant was examined on a Beckman Coulter DU800 spectrophotometer to determine the absorption spectrum. Susceptibility to various antibiotics was investigated on MA plates by using antibiotic discs containing the following: polymyxin B, $100 \mathrm{U}$; streptomycin, $50 \mu \mathrm{g}$; penicillin G, $20 \mathrm{U}$; chloramphenicol, $100 \mu \mathrm{g}$; ampicillin, $10 \mu \mathrm{g}$; cephalothin, $30 \mu \mathrm{g}$; gentamicin, $30 \mu \mathrm{g}$; novobiocin, $5 \mu \mathrm{g}$; tetracycline, $30 \mu \mathrm{g}$; kanamycin, $30 \mu \mathrm{g}$; lincomycin, $15 \mu \mathrm{g}$; oleandomycin, $15 \mu \mathrm{g}$; neomycin, $30 \mu \mathrm{g}$; and carbenicillin, $100 \mu \mathrm{g}$. The utilization of various substrates for growth was determined as described by Baumann \& Baumann (1981), using supplementation with $2 \%(\mathrm{v} / \mathrm{v})$ Hutner's mineral salts solution (Cohen-Bazire et al., 1957) and $1 \%(\mathrm{v} / \mathrm{v})$ vitamin solution (Staley, 1968). Enzyme activities were determined after incubation for $8 \mathrm{~h}$ at $30{ }^{\circ} \mathrm{C}$ by using the API ZYM system (bioMérieux).

Cell biomass for DNA extraction and for isoprenoid quinone analysis was obtained from a culture grown for 2 days in $\mathrm{MB}$ at $30^{\circ} \mathrm{C}$. Chromosomal DNA was isolated and purified according to the method described by Yoon et al. (1996), with the exception that RNase T1 was used in combination with RNase A to minimize contamination by RNA. The 16S rRNA gene was amplified by means of a
PCR using two universal primers, as described previously (Yoon et al., 1998). The sequencing of the amplified 16S rRNA gene and phylogenetic analysis were performed as described by Yoon et al. (2003). Isoprenoid quinones were analysed as described by Komagata \& Suzuki (1987) using reversed-phase HPLC. For the cellular fatty acid analysis, cell mass of strain JW-26 ${ }^{\mathrm{T}}$ and T. crocina KCTC $12721^{\mathrm{T}}$ was harvested from MA plates after cultivation for 3 days at $30{ }^{\circ} \mathrm{C}$. The fatty acids were extracted and fatty acid methyl esters prepared according to the standard protocol of the MIDI/Hewlett Packard Microbial Identification System (Sasser, 1990). The DNA G + C content was determined using the method of Tamaoka \& Komagata (1984), with the modification that the DNA was hydrolysed using nuclease P1 (Sigma) and the resultant nucleotides were analysed by reversed-phase HPLC. DNA-DNA hybridization was performed fluorometrically using the method of Ezaki et al. (1989) with photobiotin-labelled DNA probes and microdilution wells. Hybridization was performed with five replications for each sample. The highest and lowest values obtained in each sample were excluded and the means of the remaining three values are quoted as DNA-DNA relatedness values.

Morphological, cultural, physiological and biochemical characteristics of strain $\mathrm{JW}-26^{\mathrm{T}}$ are given in the species description (see below) and in Table 1. Sonicated cell extracts of strain $\mathrm{JW}-26^{\mathrm{T}}$ showed an absorption maximum at $446 \mathrm{~nm}$, indicating the presence of carotenoids. Flexirubin-type pigments were also present, as shown by the positive $\mathrm{KOH}$ test. The almost-complete 16S rRNA gene sequence of strain $\mathrm{JW}-26^{\mathrm{T}}$ comprised $1474 \mathrm{nt}$, representing approximately $96 \%$ of the Escherichia coli $16 \mathrm{~S}$ rRNA gene sequence. In the phylogenetic tree constructed using the neighbour-joining algorithm, strain

\section{Table 1. Differential phenotypic characteristics of strain $\mathrm{JW}-26^{\top}$ and the type strain of $T$. crocina}

Data for T. crocina are for strain HST1-43 ${ }^{\mathrm{T}}$ from Lee (2007) unless indicated. The two strains are aerobic, rod-shaped and positive for the following: catalase and oxidase activities, a requirement for sea salts, production of carotenoid pigments, nitrate reduction, hydrolysis of aesculin, utilization of D-glucose, D-galactose, cellobiose and D-mannose, susceptibility to cephalothin (weak for JW-26 ${ }^{\mathrm{T}}$ ), chloramphenicol, novobiocin, carbenicillin, lincomycin and oleandomycin and activities of alkaline phosphatase, esterase lipase (C8) (weak for T. crocina HST1-43 ${ }^{\mathrm{T}}$ ), leucine arylamidase, acid phosphatase and naphthol-AS-BI-phosphohydrolase (weak for T. crocina HST1-43 ${ }^{\mathrm{T}}$ ). The two strains are negative for the following: Gram stain, gliding motility, urease activity, hydrolysis of casein, gelatin, starch and Tween 80, utilization of trehalose, L-arabinose, maltose, acetate, citrate, succinate, benzoate, L-malate, pyruvate, salicin, formate and L-glutamate, susceptibility to polymyxin B, streptomycin, gentamicin, tetracycline, kanamycin and neomycin and activities of lipase (C14), valine arylamidase, cystine arylamidase, trypsin, $\alpha$-galactosidase, $\alpha$-glucuronidase, $\alpha$ glucosidase, $\beta$-glucosidase, $N$-acetyl- $\beta$-glucosaminidase, $\alpha$-mannosidase and $\alpha$-fucosidase.

\begin{tabular}{|lcc|}
\hline Characteristic & Strain JW-26 & T. $^{\text {crocina }}$ HST1-43 $^{\text {T }}$ \\
\hline Cell size $(\mu \mathrm{m})$ & $0.6-1.0 \times 1.0-3.0$ & $0.3-0.5 \times 0.7-1.1$ \\
Growth at 10 and $38{ }^{\circ} \mathrm{C}$ & + & - \\
Flexirubin-type pigments & + & - \\
Hydrolysis of agar and tyrosine & - & - \\
Utilization of D-fructose, D-xylose and sucrose & \\
Susceptibility to penicillin G and ampicillin & - & + \\
API ZYM tests for esterase $(C 4), \alpha$-chymotrypsin and $\beta$-galactosidase & + \\
\hline
\end{tabular}

${ }^{\star}$ Data for T. crocina KCTC $12721^{\mathrm{T}}$ from this study. 
JW- $26^{\mathrm{T}}$ joined the type strain of $T$. crocina with a bootstrap resampling value of $82.7 \%$ (Fig. 1). The two strains exhibited 95.5\% 16S rRNA gene sequence similarity. The relationship between strain JW-26 ${ }^{\mathrm{T}}$ and T. crocina HST $1-43^{\mathrm{T}}$ was also maintained in the trees constructed using the maximumlikelihood and maximum-parsimony algorithms (Fig. 1).

The predominant isoprenoid quinone detected in strain $\mathrm{JW}-26^{\mathrm{T}}$ was MK-6, at a peak area ratio of approximately $96 \%$. The cellular fatty acid profile of strain $\mathrm{JW}-26^{\mathrm{T}}$ is shown in Table 2, together with that of T. crocina KCTC $12721^{\mathrm{T}}$, which was also analysed in this study. The major fatty acids (constituting $>10 \%$ of total fatty acids) detected in strain JW-26 $6^{\mathrm{T}}$ were iso- $\mathrm{C}_{15: 0}(25.9 \%), \mathrm{C}_{15: 0}$ $(12.1 \%)$ and iso- $\mathrm{C}_{15: 1}(11.8 \%)$. This fatty acid profile was similar to that of T. crocina KCTC $12721^{\mathrm{T}}$, although there were differences in the proportions of some fatty acids (Table 2). Hence, no distinct chemotaxonomic properties served to differentiate strain $\mathrm{JW}-26^{\mathrm{T}}$ from T. crocina (Lee, 2007; Table 2). The DNA G + C content of strain JW $-26^{\mathrm{T}}$ was $36.8 \mathrm{~mol} \%$, which was in line with that of $T$. crocina HST $1-43^{\mathrm{T}}$ (36.2 $\pm 0.4 \mathrm{~mol} \%$; Lee, 2007). Accordingly, on the basis of the phylogenetic and chemotaxonomic data, it is appropriate to classify strain $\mathrm{JW}-26^{\mathrm{T}}$ within the genus Tamlana.

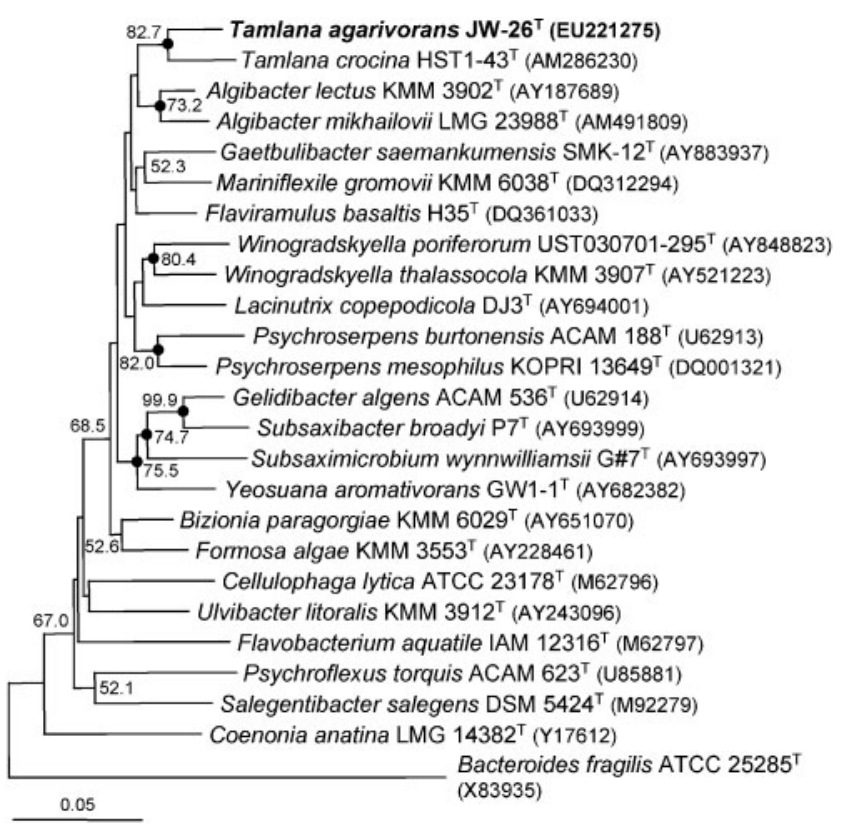

Fig. 1. Neighbour-joining phylogenetic tree, based on $16 \mathrm{~S}$ rRNA gene sequences, showing the positions of strain $\mathrm{JW}-26^{\top}, T$. crocina HST1 $-43^{\top}$ and some other related taxa. Bootstrap percentages (based on 1000 replications) $>50 \%$ are shown at branching points. Filled circles indicate that the corresponding nodes were also recovered in trees generated with the maximumlikelihood and maximum-parsimony algorithms. Bacteroides fragilis ATCC $25285^{\top}$ was used as an outgroup. Bar, 0.05 substitutions per nucleotide position.
Table 2. Cellular fatty acid compositions (\%) of strain $\mathrm{JW}-26^{\top}$ and T. crocina KCTC $12721^{\top}$

Data are from this study. Fatty acids that represented $<0.5 \%$ in both strains were omitted. -, Not detected.

\begin{tabular}{|c|c|c|}
\hline Fatty acid & Strain JW-26 ${ }^{\mathrm{T}}$ & $\begin{array}{c}\text { T. crocina KCTC } \\
12721^{\mathrm{T}}\end{array}$ \\
\hline \multicolumn{3}{|l|}{ Straight-chain } \\
\hline $\mathrm{C}_{13: 0}$ & 0.6 & 0.2 \\
\hline $\mathrm{C}_{14: 0}$ & 1.4 & - \\
\hline $\mathrm{C}_{15: 0}$ & 12.1 & 9.9 \\
\hline $\mathrm{C}_{16: 0}$ & 3.4 & 0.9 \\
\hline \multicolumn{3}{|l|}{ Unsaturated } \\
\hline $\mathrm{C}_{15: 1} \omega 6 c$ & 3.0 & 3.4 \\
\hline $\mathrm{C}_{17: 1} \omega 6 c$ & 0.9 & 1.4 \\
\hline \multicolumn{3}{|l|}{ Branched } \\
\hline iso- $\mathrm{C}_{13: 0}$ & 1.0 & 0.4 \\
\hline iso- $\mathrm{C}_{14: 0}$ & 1.4 & 1.6 \\
\hline iso- $\mathrm{C}_{15: 1}$ & 11.8 & 12.4 \\
\hline anteiso- $\mathrm{C}_{15: 1}$ & 0.7 & 1.3 \\
\hline iso- $\mathrm{C}_{15: 0}$ & 25.9 & 18.7 \\
\hline anteiso- $\mathrm{C}_{15: 0}$ & 3.2 & 5.0 \\
\hline iso- $\mathrm{C}_{16: 1}$ & - & 0.8 \\
\hline iso- $\mathrm{C}_{16: 0}$ & 2.0 & 1.2 \\
\hline iso- $\mathrm{C}_{17: 1} \omega 9 c$ & 0.5 & 0.5 \\
\hline \multicolumn{3}{|l|}{ Hydroxy } \\
\hline iso- $\mathrm{C}_{15: 0} 3-\mathrm{OH}$ & 3.5 & 5.1 \\
\hline $\mathrm{C}_{15: 0} 2-\mathrm{OH}$ & - & 1.4 \\
\hline $\mathrm{C}_{15: 0} 3-\mathrm{OH}$ & 1.9 & 1.5 \\
\hline iso- $\mathrm{C}_{16: 0} 3-\mathrm{OH}$ & 2.1 & 7.4 \\
\hline $\mathrm{C}_{16: 0} 3-\mathrm{OH}$ & 5.2 & 0.5 \\
\hline iso- $\mathrm{C}_{17: 0} 3-\mathrm{OH}$ & 9.9 & 14.3 \\
\hline $\mathrm{C}_{17: 0} 2-\mathrm{OH}$ & 0.6 & 2.4 \\
\hline $\mathrm{C}_{17: 0} 3-\mathrm{OH}$ & 0.9 & 0.7 \\
\hline Summed feature $3^{\star}$ & 5.0 & 4.8 \\
\hline \multicolumn{3}{|l|}{ Unknown $\dagger$} \\
\hline ECL 13.565 & 1.4 & 1.8 \\
\hline ECL 16.582 & 1.0 & 1.5 \\
\hline
\end{tabular}

${ }^{*}$ Summed features represent groups of two or three fatty acids which could not be separated by GLC with the MIDI system. Summed feature 3 contained $\mathrm{C}_{16: 1} \omega 7 c$ and/or iso- $\mathrm{C}_{15: 0} 2-\mathrm{OH}$.

$\dagger \mathrm{ECL}$, Equivalent chain length.

The mean value for DNA-DNA relatedness between strain JW- $26^{\mathrm{T}}$ and T. crocina KCTC $12721^{\mathrm{T}}$ was $9 \%$, when their DNAs were used individually as labelled DNA probes for cross-hybridization, indicating that strain $\mathrm{JW}-26^{\mathrm{T}}$ represents a genomic species that is different from $T$. crocina (Wayne et al., 1987). Strain JW-26 ${ }^{\mathrm{T}}$ was distinguishable from $T$. crocina by differences in terms of several phenotypic characteristics, as listed in Table 1. The phylogenetic and genetic distinctiveness and differential phenotypic properties of strain $\mathrm{JW}-26^{\mathrm{T}}$ are sufficient to show that strain $\mathrm{JW}-26^{\mathrm{T}}$ is separate from $T$. crocina (Stackebrandt \& Goebel, 1994). Therefore, on the basis of the data presented, strain JW- $-26^{\mathrm{T}}$ represents a novel species 
of the genus Tamlana, for which the name Tamlana agarivorans sp. nov. is proposed.

\section{Description of Tamlana agarivorans sp. nov.}

Tamlana agarivorans (a.ga.ri.vo'rans. N.L. n. agarum agar, algal polysaccharide; L. v. vorare to devour, to digest; N.L. part. adj. agarivorans agar-devouring).

Cells are Gram-negative, non-flagellated rods, 0.6-1.0 $\mu \mathrm{m}$ in diameter and 1.0-3.0 $\mu \mathrm{m}$ long. Colonies on MA are circular with regular margins, flat to raised, smooth, glistening, yellow in colour and $1.0-2.0 \mathrm{~mm}$ in diameter after 3 days incubation at $30{ }^{\circ} \mathrm{C}$. Growth occurs at 10 and $38{ }^{\circ} \mathrm{C}$, but not at 4 or $39^{\circ} \mathrm{C}$. The optimal pH for growth is between 7.0 and 8.0; growth occurs at $\mathrm{pH} 5.0$, but not at $\mathrm{pH}$ 4.5. Growth occurs in the presence of $0.5-6 \%(\mathrm{w} / \mathrm{v})$ $\mathrm{NaCl}$. The optimal $\mathrm{NaCl}$ concentration for growth is approximately $2 \%(\mathrm{w} / \mathrm{v})$. Anaerobic growth does not occur on MA or on MA supplemented with nitrate. Hypoxanthine, xanthine and Tweens 20,40 and 60 are not hydrolysed. $\mathrm{H}_{2} \mathrm{~S}$ is not produced. Carotenoid and flexirubin pigments are produced. The predominant menaquinone is MK-6. The major fatty acids $(>10 \%$ of total fatty acids) are iso- $\mathrm{C}_{15: 0}, \mathrm{C}_{15: 0}$ and iso- $\mathrm{C}_{15: 1}$. The DNA $\mathrm{G}+\mathrm{C}$ content of the type strain is $36.8 \mathrm{~mol} \%$ (determined by HPLC). Other phenotypic characteristics are given in Table 1 .

The type strain, JW $-26^{\mathrm{T}} \quad\left(=\mathrm{KCTC} 22176^{\mathrm{T}}=\mathrm{CCUG}\right.$ $\left.55327^{\mathrm{T}}\right)$, was isolated from seawater off Jeju Island in Korea.

\section{Acknowledgements}

This work was supported by the 21C Frontier Program of Microbial Genomics and Applications (grant MG05-0401-2-0) and the Support and Application Project of Biological Resources (grant M10508050004-06N0805-00410) from the Ministry of Science and Technology (MOST) of the Republic of Korea.

\section{References}

Baumann, P. \& Baumann, L. (1981). The marine Gram-negative eubacteria: genera Photobacterium, Beneckea, Alteromonas, Pseudomonas, and Alcaligenes. In The Prokaryotes, pp. 1302-1331. Edited by M. P. Starr, H. Stolp, H. G. Trüper, A. Balows \& H. G. Schlegel. Berlin: Springer.

Bowman, J. P. (2000). Description of Cellulophaga algicola sp. nov., isolated from the surfaces of Antarctic algae, and reclassification of Cytophaga uliginosa (ZoBell and Upham 1944) Reichenbach 1989 as
Cellulophaga uliginosa comb. nov. Int J Syst Evol Microbiol 50, 1861-1868.

Bruns, A., Rohde, M. \& Berthe-Corti, L. (2001). Muricauda ruestringensis gen. nov., sp. nov., a facultatively anaerobic, appendaged bacterium from German North Sea intertidal sediment. Int $J$ Syst Evol Microbiol 51, 1997-2006.

Cohen-Bazire, G., Sistrom, W. R. \& Stanier, R. Y. (1957). Kinetic studies of pigment synthesis by nonsulfur purple bacteria. J Cell Comp Physiol 49, 25-68.

Cowan, S. T. \& Steel, K. J. (1965). Manual for the Identification of Medical Bacteria. London: Cambridge University Press.

Ezaki, T., Hashimoto, Y. \& Yabuuchi, E. (1989). Fluorometric deoxyribonucleic acid-deoxyribonucleic acid hybridization in microdilution wells as an alternative to membrane filter hybridization in which radioisotopes are used to determine genetic relatedness among bacterial strains. Int J Syst Bacteriol 39, 224-229.

Komagata, K. \& Suzuki, K. (1987). Lipid and cell-wall analysis in bacterial systematics. Methods Microbiol 19, 161-207.

Lányí, B. (1987). Classical and rapid identification methods for medically important bacteria. Methods Microbiol 19, 1-67.

Lee, S. D. (2007). Tamlana crocina gen. nov., sp. nov., a marine bacterium of the family Flavobacteriaceae, isolated from beach sediment in Korea. Int J Syst Evol Microbiol 57, 764-769.

Reichenbach, H. (1992). The order Cytophagales. In The Prokaryotes, 2nd edn, vol. 4, pp. 3631-3675. Edited by A. Balows, H. G. Trüper, M. Dworkin, W. Harder \& K. H. Schleifer. New York: Springer.

Sasser, M. (1990). Identification of bacteria by gas chromatography of cellular fatty acids, MIDI Technical Note 101. Newark, DE: MIDI Inc.

Stackebrandt, E. \& Goebel, B. M. (1994). Taxonomic note: a place for DNA-DNA reassociation and $16 \mathrm{~S}$ rRNA sequence analysis in the present species definition in bacteriology. Int J Syst Bacteriol 44, 846-849.

Staley, J. T. (1968). Prosthecomicrobium and Ancalomicrobium: new prosthecate freshwater bacteria. J Bacteriol 95, 1921-1942.

Tamaoka, J. \& Komagata, K. (1984). Determination of DNA base composition by reversed-phase high-performance liquid chromatography. FEMS Microbiol Lett 25, 125-128.

Wayne, L. G., Brenner, D. J., Colwell, R. R., Grimont, P. A. D., Kandler, O., Krichevsky, M. I., Moore, L. H., Moore, W. E. C., Murray, R. G. E. \& other authors (1987). International Committee on Systematic Bacteriology. Report of the ad hoc committee on reconciliation of approaches to bacterial systematics. Int J Syst Bacteriol 37, 463-464.

Yoon, J.-H., Kim, H., Kim, S.-B., Kim, H.-J., Kim, W. Y., Lee, S. T., Goodfellow, M. \& Park, Y.-H. (1996). Identification of Saccharomonospora strains by the use of genomic DNA fragments and rRNA gene probes. Int J Syst Bacteriol 46, 502-505.

Yoon, J.-H., Lee, S. T. \& Park, Y.-H. (1998). Inter- and intraspecific phylogenetic analysis of the genus Nocardioides and related taxa based on 16S rRNA gene sequences. Int J Syst Bacteriol 48, 187-194.

Yoon, J.-H., Kang, K. H. \& Park, Y.-H. (2003). Psychrobacter jeotgali sp. nov., isolated from jeotgal, a traditional Korean fermented seafood. Int J Syst Evol Microbiol 53, 449-454. 